НАУКОВИЙ ВІСНИК The

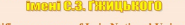
Veterinary Medicine and Biotecthologgic

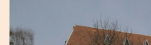
1) 11 in TH. :PIS: ХАРЧОВI ТЕХНОЛОГ Том 23 № 95 2021

\section{Науковий вісник Яьвівського національного університету ветеринарної медицини та біотехнологій імені С.3. Гжицького. Серія: Харчові технології}

\author{
Scientific Messenger of Lviv National University \\ of Veterinary Medicine and Biotechnologies.
} Series: Food Technologies https://nvlvet.com.ua/index.php/food

UDC 637.236

\title{
Development of technology of herodietic smoothies
}

\author{
L. Y. Musiy, O. Y. Tsisaryk, I. M. Slyvka
}

Stepan Gzhytskyi National University of Veterinary Medicine and Biotechnologies Lviv, Ukraine

Article info

Received 11.01.2021

Received in revised form 15.02.2021

Accepted 16.02.2021

Stepan Gzhytskyi National University of Veterinary Medicine and Biotechnologies Lviv Pekarska Str., 50, Lviv, 79010, Ukraine.

Tel.: +38-098-132-31-63 $+38-067-600-11-04$ $+38-097-986-15-44$

E-mail:musiyluba@ukr.net tsisaryk_o@yahoo.com slyvka.88@ukr.net
Musiy, L. Y., Tsisaryk, O. Y., \& Slyvka, I. M. (2021). Development of technology of herodietic smoothies. Scientific Messenger of Lviv National University of Veterinary Medicine and Biotechnologies. Series: Food Technologies, 23(95), 38-45. doi: 10.32718/nvlvet-f9507

The purpose of the work was to develop recipes and technology of smoothies with high nutritional value by enrichment with fruit and vegetable filler. Experimental studies of organoleptic, physicochemical and microbiological parameters of the strip were conducted in the laboratory of the Department of Milk and Dairy Products Technology. In the first stage, a new product was developed using different ratios of milk and fruit-vegetable base (banana and pumpkin puree in different proportions) and chia seeds. For research, 4 formulations of the strip were developed: control - milk base $75 \%$, fruit puree - $10 \%$, pumpkin puree $10 \%$, chia seeds - $5 \%$; sample № 1 - milk base $60 \%$, fruit puree - $15 \%$, pumpkin puree - $15 \%$, chia seeds $-10 \%$; sample № 2 - milk base $50 \%$, fruit puree $-20 \%$, pumpkin puree $-20 \%$, chia seeds $-10 \%$; sample № 3 - milk base $40 \%$, fruit puree - $20 \%$, pumpkin puree - $20 \%$, chia seeds $-20 \%$. Yogurt was used as a milk base. Yogurt was made by tank method. Bacterial preparation of direct application of FD DVS ABY-3 was added to the mixture cooled to a temperature of $(37 \pm 1){ }^{\circ} \mathrm{C}$. The increase in titrated and active acidity was monitored during fermentation. The titratable acidity was determined according to GOST 3624-92 "Milk and dairy products. Titrometric methods for determining acidity. Measurements of active acidity were performed using an electronic pH meter "Muttler Toledo MP220". The vegetable base was prepared as follows: the pumpkin after washing and cleaning was rubbed on a fine grater, then crushed with a blender to obtain a more homogenized mass. Heat treatment of the crushed mass was performed in a water bath at a temperature of $+74{ }^{\circ} \mathrm{C}$ for $25 \mathrm{~min}$. The banana was washed, peeled and crushed with a blender to obtain a homogeneous mass. Heat treatment of the crushed mass was performed in a water bath at a temperature of $+74{ }^{\circ} \mathrm{C}$ for $25 \mathrm{~min}$. Chia seeds were cleaned of damaged specimens, dust, dirt and other impurities, washed with water for 10 minutes. at a temperature of $20^{\circ} \mathrm{C}$. Chia seeds were mixed with yogurt in a ratio of $1: 10$ at a temperature of $37^{\circ} \mathrm{C}$. Left to swell for $30 \mathrm{~min}$. Then the estimated amount was made to the bulk. Organoleptic and physicochemical parameters according to DSTU 4343:2004 "Yogurts. General technical conditions". The microbiological parameters of the product were studied according to DSTU IDF 117B:2003 "Yogurt. Determination of the number of characteristic microorganisms. The method of counting colonies at a temperature of $37^{\circ} \mathrm{C}$ ". The introduction of chia seeds affected the energy value of the product. The highest energy value is calculated for the sample using $20 \%$ of chia seeds $-110 \mathrm{kcal}$. The lowest energy value for control is $70.6 \mathrm{kcal}$, in which the share of milk base prevails. The introduction of chia seeds in the product reduces the number of lactic acid bacteria in the test samples of the smoothies, which in particular correlates with the titrated acidity of the product. When examining the presence of pathogenic microflora in the samples of the strip, it was found that all samples met the requirements for microbiological safety. The number of viable cells of Escherichia coli and bifidobacteria gives the product probiotic properties. According to the results of organoleptic parameters, the best shelf life for the strip is 14 days. All samples of the strip after 14 days had a sour taste and smell and a slight serum. The lowest value of titratable acidity for 14 days of storage was in the sample when using more chia seeds $-20 \%$. At 21 days of storage in all samples of the strip, the titrated acidity was higher than the allowable value. To expand the range of dairy products with high nutritional value and heroic properties, it is recommended to use in the technology of the strip $50 \%$ milk base (yogurt), $20 \%$ banana puree, $20 \%$ pumpkin puree and $10 \%$ chia seeds.

Key words: elderly people, yogurt, smoothies, technology, energy value, organoleptic indicators. 


\title{
Розроблення технології смузі геродістичного призначення
}

\author{
Л. Я. Мусій, О. Й. Цісарик, І. М. Сливка
}

Львівський національний університет ветеринарної медицини та біотехнологій імені С. 3. Гжицького, м. Львів, Україна

Метою роботи було розробити рецептури та технологію смузі з підвищеною харчовою иінністю шляхом збагачення фруктово-рослинним наповнювачем. Експериментальні дослідження органолептичних, фізико-хімічних та мікробіологічних показників смузі проводилися у лабораторії кафедри технологї молока і молочних продуктів. На першому етапі розробляли рецептуру нового продукту, використовуючи різні співвідношення молочної $і$ фруктово-рослинної основи (бананового і гарбузового пюре у різних пропориіях) та насіння Чіа. Для досліджень було розроблено 4 рецептури смузі: контроль - молочна основа 75 \%, фруктове пюре $10 \%$, гарбузове пюре - $10 \%$, насіння Чіа - $5 \%$; зразок № 1 -молочна основа $60 \%$, фруктове пюре - $15 \%$, гарбузове пюре - $15 \%$, насіння Чіа - $10 \%$; зразок № 2 - молочна основа $50 \%$, фруктове пюре - $20 \%$, гарбузове пюре - $20 \%$, насіння Чіа - $10 \%$; зразок № 3 - молочна основа $40 \%$, фруктове пюре - $20 \%$, гарбузове пюре - 20 \%, насіння Чіа - $20 \%$ Як молочну основу використовували йогурт. Йогурт виготовляли резервуарним способом. У охолоджену до температури (37 \pm 1$)^{\circ} \mathrm{C}$ суміш вносили бактеріальний препарат прямого внесення FD DVS ABY-3. Протягом сквашування контролювали наростання титрованої та активної кислотності. Титровану кислотність визначали за ГОСТ 3624-92 “Молоко і молочні продукти. Титрометричні методи визначення кислотності”. Вимірювання активної кислотності проводили за допомогою електронного рН-метра “Миtтег Тоlеdо МР220”. Рослинну основу готували таким чином: гарбуз після миття та очищення натирали на дрібній тертиі, потім подрібнювали блендером для отримання більш гомогенізованої маси. Теплову обробку подрібненої маси проводили на водяній бані при температурі $+74{ }^{\circ} \mathrm{C}$ протягом 25 хв. Банан мили, очищали від шкірки та подрібнювали блендером до отримання однорідної гомогенної маси. Теплову обробку подрібненої маси проводили на водяній бані при температурі $+74{ }^{\circ}$ С протягом 25 хв. Насіння Чіа очищали від пошкоджених екземплярів, пилу, бруду та інших сторонніх домішок, промивали водою протягом 10 хв. при температурі $20{ }^{\circ} \mathrm{C}$. Насіння Чіа змішували з йогуртом у співвідношенні 1 : 10 при температурі $37^{\circ} \mathrm{C}$. Залишали для набухання на 30 хв. Потім розрахункову кількість вносили до основної маси. У готовому продукті досліджували органолептичні та фізико-хімічні показники згідно з ДСТУ 4343:2004 “Йогурти. Загальні технічні умови”. Мікробіологічні показники продукту досліджували згідно з ДСТУ IDF 117В:2003 “Йогурт. Визначення кількості характерних мікроорганізмів. Метод підрахунку колоній за температури $37{ }^{\circ} \mathrm{C} ”$. Внесення насіння Чіа вплинуло на енергетичну иінність продукту. Найвища енергетична иінність розрахована для зразка з використанням 20 \% насіння Чіа - 110 ккал. Найнижча енергетична иінність для контролю - 70,6 ккал, в якому переважає частка молочної основи. Внесення насіння Чіа у продукт зменшує кількість молочнокислих бактерій у дослідних зразках смузі, шио зокрема корелює із титрованою кислотністю продукту. При дослідженні наявності патогенної мікрофлори у зразках смузі встановлено, щчо всі зразки відповідали вимогам за мікробіологічною безпечністю. Кількість життєздатних клітин ацидофільної палички та біфідобактерій надає продукту пробіотичних властивостей. За результатами органолептичних показників - найкращчий термін зберігання для смузі 14 діб. Всі зразки смузі після 14 доби мали кислий смак $і$ запах та незначне виділення сироватки. Найнижча величина титрованої кислотності за 14 діб зберігання була у зразка при використанні більиої кількості насіння Чіа - $20 \%$. На 21 добу зберігання у всіх зразках смузі титрована кислотність була вищою за допустиме значення. Для розширення асортименту молочних продуктів із підвищеною харчовою цуінністю та геродієтичними властивостями рекомендовано використовувати у технологї смузі 50 \% молочної основи (йогурт), 20 \% бананового пюре, $20 \%$ гарбузового пюре та 10 \% насіння Чіа.

Ключові слова: люди похилого віку, йогурт, смузі, технологія, енергетична ияінність, органолептичні показники.

\section{Вступ}

Сучасним трендом у молочній промисловості $\epsilon$ створення продуктів 3 оздоровчими властивостями, зокрема для людей похилого віку (Gavrilova et al., 2019; García-Burgos et al., 2020; Alexeev et al., 2020). Концепція здорового харчування людей похилого віку полягає у створенні нових функціональних продуктів, які не тільки задовольняють фізіологічні потреби організму людини в харчових речовинах і енергії, а й виконують профілактичні та лікувальні функції (Tjurikova \& Peresichnyj, 2015). Раціональне харчування людей літнього віку вимагає збільшення асортименту молочних продуктів для профілактики та корекції захворювань. Розроблення продуктів геродієтичного спрямування дозволить зменшити кількість захворювань людей похилого віку (Gasmalla et al., 2017; Sylchuk et al., 2018).

Асортимент молочних продуктів геродієтичного напрямку широко представлений на ринку харчових продуктів в економічно розвинутих країнах і практично з поодинокими видами присутній в інших державаx (Ribeiro et al., 2019). Саме така ситуація, як присутність поодиноких зразків геропродуктів, тобто приз- начених для людей старшого віку, характерна для вітчизняного молочного ринку. На сьогодні "Геролакт” (ТМ “Яготинський”), - це практично “реанімований” один вид геропродукту як представник із минулих фундаментальних наукових розробок. Він був створений на основі вивчення сукупності таких факторів, як особливості структури харчування та медичних аспектів процесу старіння, що впливають на довголіття (Dmytrovska, 2016).

Серед багатьох груп харчових продуктів стосовно можливості створення нових збагачених продуктів підвищеної харчової і біологічної цінності значне зацікавлення викликає смузі (Tiwari, 2018; Guazi et al., 2019). Смузі - це густий, пюреподібний продукт 3 використанням молочної і немолочної основи, приготовлений 3 додаванням натуральних складників для профілактики та корегування захворювань людей, зокрема людей похилого віку (Castillejo et al., 2015; González-Tejedor et al., 2017).

Для надання продукту (смузі) геродієтичних властивостей як фруктово-рослинний наповнювач використовували бананове та гарбузове пюре, а також насіння Чіа. Рецептурні складники мають ряд оздоровчих властивостей, зокрема допомагають при ліку- 
ванні захворювань нирок, печінки, анемії, атеросклерозі, гіпертонії, депресії, печії, набряклості кінцівок (Fontes et al., 2017; Kaur et al., 2019; Kulczynski et al., 2019).

Високі функціонально-технологічні властивості насіння Чіа та вміст фізіологічно важливих нутрієнтів $\epsilon$ передумовою використання 3 метою регулювання технологічних характеристик і поліпшення харчової та біологічної цінності продуктів (Attalla \& ElNeamah, 2017).

Насіння Чіа - натуральний продукт, який має цілющі властивості. Важливою особливістю хімічного складу Чіа є повна відсутність глютену, що дозволяє його використовувати в продуктах харчування, призначених для людей, хворих на целіакію (Diakonova \& Stepanova, 2016).

Насіння Чіа містить найбільше омега-3 жирних кислот, зокрема 41-59 \% альфа-ліноленової (омега-3), 18-25 \% лінолевої (омега-6) кислоти у співвідношенні $1: 4-1: 6$, сприятливому для кращого засвоєння незамінних ПНЖК в організмі людини (Dyakonova \& Stepanova, 2016).

Технологія смузі дозволяє використовувати молочну основу та природні біокоректори, які утворюють не тільки відмінні органолептичні властивості, а й задовольняють фізіологічні потреби в життєво необхідних біологічно активних речовинах. Використання натуральної сировини, зокрема банана, гарбуза та насіння Чіа у технології смузі на основі йогурту розширить асортимент молочних продуктів геродієтичного призначення.

Метою роботи було розробити рецептури та технологію смузі з підвищеною харчовою цінністю шляхом збагачення фруктово-рослинним наповнювачем.

\section{Матеріал і методи досліджень}

Експериментальні дослідження органолептичних, фізико-хімічних та мікробіологічних показників зразків смузі проводилися у лабораторії кафедри технології молока і молочних продуктів Львівського національного університету ветеринарної медицини та біотехнологій імені С. 3. Гжицького.

На першому етапі розробляли рецептуру нового продукту, використовуючи різні співвідношення молочної i фруктово-рослинної основи (бананового i гарбузового пюре у різних пропорціях) та насіння Чіа.

Для досліджень було розроблено 4 рецептури смузі:

- контроль - молочна основа - $75 \%$, фруктове пюре $-10 \%$, гарбузове пюре - $10 \%$, насіння Чіа $-5 \%$ (молочна основа $75 \%$ : фруктово-рослинне пюре $25 \%$ );

- зразок 1 - молочна основа - $60 \%$, фруктове пюре - $15 \%$, гарбузове пюре - $15 \%$, насіння Чіа - 10 \% (молочна основа $60 \%$ : фруктово-рослинне пюре $40 \%$ ).

- зразок 2 - молочна основа - $50 \%$, фруктове пюре - $20 \%$, гарбузове пюре - $20 \%$, насіння Чіа - $10 \%$ (молочна основа $50 \%$ : фруктово-рослинне пюре $50 \%$ );

- зразок 3 - молочна основа - $40 \%$, фруктове пюре - 20 \%, гарбузове пюре - $20 \%$, насіння Чіа - 20 \% (молочна основа $40 \%$ : фруктово-рослинне пюре $60 \%$ ).

Як молочну основу використовували йогурт. Йогурт виготовляли резервуарним способом. Охолодже- не молоко (титрована кислотність $\left.18^{\circ} \mathrm{T}\right)$ направляли на нормалізацію знежиреним молоком (м. ч. ж. $0,05 \%$ ) до масової частки жиру в нормалізованій суміші 1,5 \%. Після нормалізації суміш направляли на пастеризацію при температурі $(95 \pm 1){ }^{\circ} \mathrm{C}$ з витримкою 5 хв. Після пастеризації нормалізовану суміш охолоджували. В охолоджену до температури $(37 \pm 1)^{\circ} \mathrm{C}$ суміш вносили бактеріальний препарат прямого внесення FD DVS ABY-3, до складу якого входить Lactobacillus acidophilus La-5, BB-12, Lactobacillus delbrueckii subsp. bulgaricus, Streptococcus salivarius subsp. thermophilus ("Хр. Хансен, Україна"). Для рівномірно розподілення культури застосовують перемішування протягом 10-15 хв. Після внесення культури суміш піддавали ферментації за температури $(37 \pm 1){ }^{\circ} \mathrm{C}$. Протягом сквашування контролювали наростання титрованої та активної кислотності. Титровану кислотність визначали за ГОСТ 3624-92 "Молоко і молочні продукти. Титрометричні методи визначення кислотності”. Вимірювання активної кислотності проводили за допомогою електронного pH-метра "Muttler Toledo MP220". Сквашування суміші проводять до досягнення активної кислотності 4,68 од. $\mathrm{pH}$. Тривалість сквашування 4 год. Титрована кислотність в кінці сквашування $76^{\circ} \mathrm{T}$.

Рослинну основу готували таким чином: гарбуз після миття та очищення натирали на дрібній тертці, потім подрібнювали блендером для отримання більш гомогенізованої маси. Теплову обробку подрібненої маси проводили на водяній бані при температурі $+74{ }^{\circ} \mathrm{C}$ протягом 25 хв (гарбуз) для пом'якшення волокон і отримання продукту м'якшої консистенції.

Банан мили, очищали від шкірки та подрібнювали блендером до отримання однорідної гомогенної маси. Теплову обробку подрібненої маси проводили на водяній бані при температурі $+74{ }^{\circ} \mathrm{C}$ протягом 25 хв.

Насіння Чіа очищали від пошкоджених екземплярів, пилу, бруду та інших сторонніх домішок, промивали водою протягом 10 хв при температурі $20^{\circ} \mathrm{C}$. Насіння Чіа змішували з йогуртом у співвідношенні $1: 10$ при температурі $37^{\circ} \mathrm{C}$. Залишали для набухання на 30 хв. Потім розрахункову кількість вносили до основної маси.

У готовому продукті досліджували органолептичні та фізико-хімічні показники згідно з ДСТУ 4343:2004 “Йогурти. Загальні технічні умови".

Мікробіологічні показники продукту досліджували згідно ДСТУ IDF 117В:2003 “Йогурт. Визначення кількості характерних мікроорганізмів. Метод підрахунку колоній за температури $37^{\circ} \mathrm{C}$ ".

\section{Результати та їх обговорення}

Використання біологічно активних харчових компонентів у технології смузі можуть підвищити якість життя людей похилого віку, виконуючи при цьому як регуляторну, так і функціональну дію. Незамінними у харчуванні людей похилого віку є молочні продукти. В таблиці 1 показано фізіологічні функції компонентів смузі для людей похилого віку. 
Таблиця 1

Фізіологічні функції компонентів смузі для людей похилого віку

\begin{tabular}{|c|c|c|}
\hline $\begin{array}{l}\text { № } \\
\text { П/ח }\end{array}$ & Сировина & Характеристика \\
\hline 1. & Йогурт & $\begin{array}{l}\text { Джерело кальцію. Йогурт позитивно впливає на травлення, корисний для кісток і суглобів, поліпшує } \\
\text { стан судин. Запобігає виникненню раку кишківника. Сприяє кращому засвоєнню мінералів і вітамінів, } \\
\text { зміцнює імунітет. Йогурт сприяє активнішому виробленню інтерферону }\end{array}$ \\
\hline 2. & Банан & $\begin{array}{l}\text { Джерело калію. Допомагають при лікуванні захворювань нирок, печінки, анемії, атеросклерозі, гіпер- } \\
\text { тонії, депресії, печії, набряклості кінцівок, запорі. Корисні при діареї, артриті, подагрі, туберкульозі, } \\
\text { порушенні функції нирок і сечовидільної системи }\end{array}$ \\
\hline 3. & Гарбуз & $\begin{array}{l}\text { Джерело вітаміну А. Природний вітамінно-мінеральний комплекс. Використовують у разі ожиріння, } \\
\text { захворювання нирок, печінки, серцево-судинної системи, гіпертонії, атеросклерозу, при холециститах, } \\
\text { колітах, діабеті та порушенні обміну речовин. В гарбузі міститься вітамін К, який сприяє згортанню } \\
\text { крові }\end{array}$ \\
\hline 4. & $\begin{array}{c}\text { Насіння } \\
\text { Чіа }\end{array}$ & $\begin{array}{l}\text { Джерело омега-3 жирних кислот. Вживання в їжу насіння Чіа забезпечує профілактику серцево-- } \\
\text { судинних і онкологічних захворювань, блокує запальні процеси в організмі, нормалізує стан нервової } \\
\text { системи, зменшує ступінь тривожності та підвищує активність мозку. Чіа покращує метаболізм та } \\
\text { допомагає знизити вагу. Чіа ефективно допомагає у лікуванні депресії, епілепсії, склерозу і при хворобі } \\
\text { Альцгеймера та нормалізує тиск }\end{array}$ \\
\hline
\end{tabular}

При встановленні дози фруктово-рослинного пюре та насіння Чіа намагались максимально збагатити продукт, а також зберегти добрі органолептичні та необхідні фізико-хімічні і структурно-механічні властивості смузі. Нами було розроблено рецептури смузі, які наведені в таблиці 2. За контроль було обрано
75 \% молочної основи (натуральний йогурт) та $25 \%$ фруктово-рослинного пюре. Таке поєднання молочної i фруктово-рослинної основи характерне для смузі виробництва компанії “Молокія”. Для дослідних зразків смузі молочна основа становила 60, 50 і $40 \%$, відповідно фруктово-рослинна - 40, 50 і 60 \%.

\section{Таблиця 2}

Рецептури на смузі з фруктово-рослинним пюре на 1000 кг готового продукту без урахування втрат

\begin{tabular}{lcccc}
\hline Назва рецептурного складника & Контроль & Зразок 1 & Зразок 2 & Зразок 3 \\
\hline Йогурт з м. ч. ж. 1,5 \%, кг & 750 & 600 & 500 & 400 \\
Фруктове пюре, кг & 100 & 150 & 200 & 200 \\
Рослинне пюре, кг & 100 & 150 & 200 & 200 \\
Насіння Чіа & 50 & 100 & 100 & 200 \\
Всього & 1000 & 1000 & 1000 & 1000 \\
\hline
\end{tabular}

Після внесення компонентів у йогурт та блендерування оцінювали органолептичні показники зразків смузі. Внесення різного співвідношення фруктового та рослинного пюре при виробництві смузі вплинуло на органолептичні властивості готового продукту. Результати органолептичної оцінки наведені у табл. 3. Дослідні зразки смузі оцінювали за консистенцією і зовнішнім виглядом, смаком і запахом, а також кольором.

Важливим показником при оцінці органолептичних показників було проаналізувати консистенцію продукту, адже смузі - це густий, пюреподібний напій.

Згідно $з$ органолептичною оцінкою контрольний зразок смузі характеризувався кисломолочним смаком, в міру солодким, 3 приємним смаком і запахом банана та гарбуза; пюреподібною консистенцією середньої густини 3 поодиноким включенням насіння Чіа; колір світло-оранжевий. При використанні різного співвідношення молочної основи та фруктоворослинного наповнювача у технології смузі найкращими органолептичними показниками характеризувався зразок 2 при використанні молочної основи $50 \%$, бананового пюре - $20 \%$, гарбузового пюре $20 \%$ та насіння Чіа - $10 \%$ (молочна основа $50 \%$ : фруктово-рослинне пюре 50 \%). Смузі мав кисломолочний, ніжний приємний смак із запахом банана та гарбуза 3 горіховим присмаком, колір оранжевий 3 коричневими зернами насіння Чіа та густу, пюреподібну консистенцію, характерну для смузі. При використанні 40 і $60 \%$ фруктово-рослинного наповнювача зразки смузі характеризувалися гіршими органолептичними показниками. Зокрема, при використанні $60 \%$ фруктово-рослинного наповнювача напій характеризувався дуже щільною та густою консистенцію 3 великою кількістю насіння Чіа, з'являлася хрусткість при розжовуванні.

Отже, враховуючи органолептичні властивості, рекомендуємо використовувати у технології смузі $50 \%$ молочної основи (натурального йогурту) та $50 \%$ фруктово-рослинного наповнювача (бананове пюре 20 \%, гарбузове пюре - $20 \%$, насіння Чіа - $10 \%$ ).

Внесення фруктово-рослинного наповнювача при виробництві смузі геродієтичного призначення має вплив на фізико-хімічні показники готового продукту. Результати досліджень фізико-хімічних показників зразків смузі з фруктово-рослинними наповнювачами наведені у табл. 4. За результатами досліджень встановлено, що внесення насіння Чіа вплинуло на масову частку жиру, білка, кислотність та умовну в'язкість. 
Таблиця 3

Органолептичні показники зразків смузі

\begin{tabular}{|c|c|c|c|}
\hline \multirow[b]{2}{*}{ Зразки кефіру } & \multicolumn{3}{|c|}{ Показники } \\
\hline & $\begin{array}{c}\text { Зовнішній вигляд і } \\
\text { консистенція }\end{array}$ & Смак і запах & Колір \\
\hline $\begin{array}{c}\text { Контроль (молочна осно- } \\
\text { ва } 75 \% \text { : фруктово- } \\
\text { рослинне пюре } 25 \%)\end{array}$ & $\begin{array}{c}\text { Пюреподібна консистенція, } \\
\text { однорідна, середньої гус- } \\
\text { тини з поодиноким вклю- } \\
\text { ченням насіння Чіа } \\
\end{array}$ & $\begin{array}{c}\text { Кисломолочний смак, в міру } \\
\text { солодкий, з приємним сма- } \\
\text { ком і запахом банана та } \\
\text { гарбуза } \\
\end{array}$ & $\begin{array}{c}\text { Світло-оранжевий, рівномі- } \\
\text { рний за всією масою з поо- } \\
\text { динокими коричневими } \\
\text { зернами насіння Чіа }\end{array}$ \\
\hline $\begin{array}{c}\text { Зразок } 1 \text { (молочна основа } \\
60 \% \text { : фруктово-рослинне } \\
\text { пюре } 40 \%)\end{array}$ & $\begin{array}{c}\text { Пюреподібна консистенція, } \\
\text { однорідна, в міру густа } 3 \\
\text { включенням насіння Чіа }\end{array}$ & $\begin{array}{c}\text { Приємний, кисломолочний, } \\
\text { ніжний, смак і запах банана } \\
\text { та гарбуза, з горіховим при- } \\
\text { смаком } \\
\end{array}$ & $\begin{array}{c}\text { Оранжевий, рівномірний за } \\
\text { всією масою з коричневими } \\
\text { зернами насіння Чіа }\end{array}$ \\
\hline $\begin{array}{c}\text { Зразок } 2 \text { (молочна основа } \\
50 \%: \text { фруктово-рослинне } \\
\text { пюре } 50 \%)\end{array}$ & $\begin{array}{c}\text { Однорідна, густа, щільна, } \\
\text { пюреподібна консистенція } \\
3 \text { включенням насіння Чіа }\end{array}$ & $\begin{array}{c}\text { Чистий, кисломолочний, } \\
\text { ніжний з приємним смаком і } \\
\text { запахом банана та гарбуза } 3 \\
\text { горіховим присмаком } \\
\end{array}$ & $\begin{array}{c}\text { Оранжевий, рівномірний за } \\
\text { всією масою з коричневими } \\
\text { зернами насіння Чіа }\end{array}$ \\
\hline $\begin{array}{c}\text { Зразок } 3 \text { (молочна основа } \\
40 \% \text { : фруктово-рослинне } \\
\text { пюре } 60 \% \text { ) }\end{array}$ & $\begin{array}{l}\text { Однорідна, дуже густа } \\
\text { консистенція } 3 \text { великою } \\
\text { кількістю насіння Чіа }\end{array}$ & $\begin{array}{c}\text { Чистий, кисломолочний, } \\
\text { ніжний з приємним смаком і } \\
\text { запахом банана та гарбуза } 3 \\
\text { надто вираженим горіховим } \\
\text { присмаком } \\
\end{array}$ & $\begin{array}{c}\text { Оранжевий з чорними вкра- } \\
\text { пленнями насіння Чіа, рів- } \\
\text { номірний за всією масою }\end{array}$ \\
\hline
\end{tabular}

У насінні Чіа - великий вміст природних антиоксидантів, таких як кафеїнова і хлорогенова кислоти, мірицетин, кемпферол і флавоноли (Diakonova \& Stepanova, 2016). Тому найвищим показником титрованої та активної кислотності характеризувався контрольний зразок при використанні найменшої кількості насіння Чіа $-5 \%\left(84^{\circ} \mathrm{T}\right.$ та 4,4 од. $\left.\mathrm{pH}\right)$ та найбільшої кількості молочної основи. Використання найбільшої кількості насіння Чіа (20 \%) призвело до зменшення титрованої та активної кислотності. Усі дослідні зразки смузі характеризувалися підвищеною умо- вною в'язкістю, порівняно $з$ контролем. Внесення більшої кількості наповнювача, зокрема насіння Чia, i призвело до збільшення в'язкості, що є важливою характеристикою при виробництві смузі.

Споживчі властивості функціональних продуктів включають харчову цінність, смакові якості та фізіологічний вплив. У таблиці 5 наведено дані щодо енергетичної цінності у 100 г рецептурних складників. Найвищою енергетичною цінністю характеризується насіння Чіа - 318,6 ккал у 100 г, а найнижчою гарбуз $-22,2$ ккал.

\section{Таблиця 4}

Фізико-хімічні показники зразків кефіру

\begin{tabular}{|c|c|c|c|c|}
\hline Назва показника & Контроль & Зразок 1 & Зразок 2 & Зразок 3 \\
\hline Масова частка жиру, \% & 1,5 & 1,6 & 1,65 & 1,7 \\
\hline Масова частка білка, \% & 3,0 & 3,2 & 3,3 & 3,5 \\
\hline Кислотність титрована, ${ }^{\circ} \mathrm{T}$ & 84 & 80 & 79 & 76 \\
\hline Кислотність активна, од. pH & 4,4 & 4,51 & 4,57 & 4,68 \\
\hline Умовна в'язкість, с & 75 & 89 & 110 & 135 \\
\hline
\end{tabular}

\section{Таблиця 5}

Харчова і біологічна цінність рецептурних складників смузі у 100 г

\begin{tabular}{lccccc}
\hline $\begin{array}{c}\text { Рецептурні } \\
\text { складники }\end{array}$ & Білки, г & Жири, г & Вуглеводи, г & $\begin{array}{c}\text { Енергетична } \\
\text { цінність, ккал }\end{array}$ & $\begin{array}{c}\text { Енергетична } \\
\text { цінність, кДж }\end{array}$ \\
\hline Йогурт & 3,0 & 1,5 & 8,0 & 57,5 & 240,6 \\
Банан & 1,0 & 0,2 & 22,0 & 93,8 & 392,5 \\
Гарбуз & 1,0 & 0,1 & 4,4 & 22,2 & 92,9 \\
Насіння Чіа & 21,0 & 30,0 & 6,15 & 318,6 & 1333,0 \\
\hline
\end{tabular}

Внесення насіння Чіа при виробництві смузі підвищує харчову та біологічну цінність 100 г продукту та збагачує продукт білком і жирами, зокрема поліненасиченими жирними кислотами. Найвища енергети- чна цінність розрахована для зразка з використанням $20 \%$ насіння Чіа - 110 ккал. Найнижча енергетична цінність - 70,6 ккал, в якому переважає частка молочної основи (табл. 6). 


\section{Таблиця 6}

Енергетична цінність смузі у100 г продукту

\begin{tabular}{lc}
\hline Зразки смузі & Енергетична цінність, ккал \\
\hline Контроль & 70,6 \\
Зразок 1 & 83,8 \\
Зразок 2 & 83,9 \\
Зразок 3 & 110,0 \\
\hline
\end{tabular}

Дослідження мікробіологічних показників зразків смузі проводили на першу добу зберігання (табл. 7). Аналізуючи дані таблиці, можна зробити висновок: кількість молочнокислих бактерій в продукті на поча- тку зберігання відповідає необхідній кількості, для надання продукту функціональних властивостей. Внесення насіння Чіа у продукт зменшує кількість молочнокислих бактерій у дослідних зразках смузі, що, зокрема, корелює із титрованою кислотністю продукту. Найвищу кількість молочнокислих бактерій зареєстровано для контрольного зразка. При дослідженні наявності патогенної мікрофлори у зразках смузі встановлено, що всі зразки відповідали вимогам за мікробіологічною безпечністю. Кількість життєздатних клітин ацидофільної палички та біфідобактерій надає продукту пробіотичних властивостей.

\section{Таблиця 7}

Мікробіологічні показники зразків

\begin{tabular}{|c|c|c|c|c|}
\hline Показник & Контроль & Зразок 1 & Зразок 2 & Зразок 3 \\
\hline $\begin{array}{l}\text { Кількість життєздатних молочнокислих бактерій (Lactobacillus bulgaricus, } \\
\text { Streptococcus thermophilus), КУО в } 1 \text { см}^{3}\end{array}$ & $3,1 \times 10^{8}$ & $2,8 \times 10^{8}$ & $2,7 \times 10^{8}$ & $2,2 \times 10^{8}$ \\
\hline $\begin{array}{l}\text { Кількість життєздатних молочнокислих бактерій Lactobacillus acidophilus } \\
\text { La-5, КУО в } 1 \text { см}^{3}\end{array}$ & $7,3 \times 10^{8}$ & $6,0 \times 10^{8}$ & $5,6 \times 10^{8}$ & $3,2 \times 10^{8}$ \\
\hline Кількість життєздатних молочнокислих бактерій ВВ-12, КУО в 1 см³ & $4,9 \times 10^{9}$ & $3,7 \times 10^{9}$ & $3,4 \times 10^{9}$ & $1,9 \times 10^{9}$ \\
\hline Бактерії групи кишкових паличок (коліформи), в $0,1 \mathrm{~cm}^{3}$ & відсутні & відсутні & відсутні & відсутні \\
\hline Патогенні мікроорганізми, в тому числі бактерії роду Salmonella в 25 г & відсутні & відсутні & відсутні & відсутні \\
\hline Staphylococcus aureus, в $1,0 \mathrm{~cm}^{3}$ & відсутні & відсутні & відс & відсутні \\
\hline О в 1 г, не більше ніж & відсутні & відсутні & відсутні & відсутні \\
\hline Плісняві гриби, КУО в 1 г, не більше ніж & відсутні & відсутні & відсутні & відсутні \\
\hline
\end{tabular}

Смузі - це густий напій, який споживають у свіжому вигляді. Проте для підприємств молочної промисловості важливим показником є термін реалізації готового продукту.

3 метою встановлення терміну зберігання продукту протягом зберігання досліджували зміни органолептичних показників та титрованої кислотності. Зразки смузі зберігали за температури $4 \pm 2{ }^{\circ} \mathrm{C}$ протягом 21 доби. Контрольний зразок до 14 діб зберігання повністю відповідав вимогам за всіма показниками (табл. 8). Після 14 доби контрольний зразок характе- ризувався нечистим, злегка кислуватим смаком і запахом та виділенням сироватки. Дослідні зразки смузі протягом цього періоду зберігали чистий без сторонніх присмаків і запахів, виражений приємний кисломолочний смак і запах з присмаком банана та гарбуза. Всі зразки смузі після 14 доби зберігання характеризувалися кислим смаком і запахом. За результатами органолептичних показників найкращий термін зберігання для смузі 14 діб. Всі зразки смузі після 14 доби мали дещо кислий смак і запах та незначне виділення сироватки.

\section{Таблиця 8}

Зміна органолептичних показників смузі протягом зберігання

\begin{tabular}{|c|c|c|c|c|c|}
\hline \multirow{2}{*}{ Показники } & \multirow{2}{*}{$\begin{array}{l}\text { Тривалість } \\
\text { зберігання, } \\
\text { діб }\end{array}$} & \multicolumn{4}{|c|}{ Зразки смузі } \\
\hline & & Контроль & Зразок 1 & Зразок 2 & Зразок 3 \\
\hline Смак та запах & $\begin{array}{c}0 \ldots 7 \\
7 \ldots 14 \\
14 \ldots 21 \\
\end{array}$ & \multicolumn{4}{|c|}{$\begin{array}{l}\text { Кисломолочний смак, в міру солодкий, з приємним смаком і запахом банана та гарбуза } \\
\text { Кисломолочний смак, в міру солодкий, з приємним смаком і запахом банана та гарбуза } \\
\text { Дещо кислуватий, смак і запах }\end{array}$} \\
\hline \multirow[t]{2}{*}{$\begin{array}{l}\text { Консистенція та } \\
\text { зовнішній ви- } \\
\text { гляд }\end{array}$} & $7 \ldots 14$ & $\begin{array}{c}\text { Пюреподібна одно- } \\
\text { рідна, середньої } \\
\text { густини з поодино- } \\
\text { ким включенням } \\
\text { насіння Чіа }\end{array}$ & $\begin{array}{c}\text { Пюреподібна, одно- } \\
\text { рідна, в міру густа } 3 \\
\text { включенням насіння } \\
\text { Чіа }\end{array}$ & $\begin{array}{l}\text { Пюреподібна, } \\
\text { густа, щільна, з } \\
\text { включенням на- } \\
\text { сіння Чіа }\end{array}$ & $\begin{array}{c}\text { Однорідна, дуже } \\
\text { густа з великою } \\
\text { кількістю насіння } \\
\text { Чіа }\end{array}$ \\
\hline & $14 \ldots 21$ & Пюреподібна однор & $\begin{array}{r}\text { на, середньої густини } \\
\text { незначним виділе }\end{array}$ & $\begin{array}{l}\text { одиноким включ } \\
\text { и сироватки }\end{array}$ & ям насіння Чіа та \\
\hline Колір & $0 \ldots 21$ & $\begin{array}{c}\text { Світло-оранжевий, } \\
\text { рівномірний за всією } \\
\text { масою з поодиноки- } \\
\text { ми коричневими } \\
\text { зернами насіння Чіа }\end{array}$ & \multicolumn{3}{|c|}{$\begin{array}{c}\text { Оранжевий, рівномірний за всією масою з поодинокими корич- } \\
\text { невими зернами насіння Чіа }\end{array}$} \\
\hline
\end{tabular}

Важливим етапом роботи було дослідити зміну кислотності смузі під час зберігання за температури
$4 \pm 2{ }^{\circ} \mathrm{C}$ (рис. 1). Антиоксиданти насіння Чіа захищають організм від окислювального стресу, вільних 
радикалів, передчасного старіння. За вмістом антиоксидантів насіння Чіа перевершує навіть свіжі ягоди чорниці (Diakonova \& Stepanova, 2016).

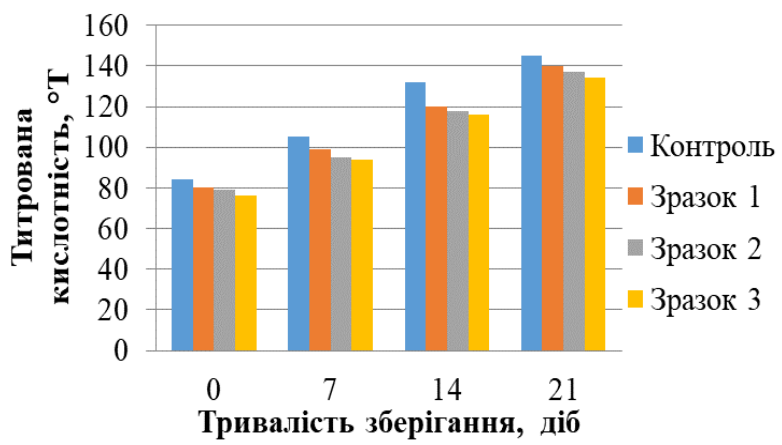

Рис. 1. Зміна титрованої кислотності зразків смузі протягом зберігання за температури $(4 \pm 2){ }^{\circ} \mathrm{C}$

На початку зберігання титрована кислотність у зразках смузі 1-3 становила $76 \ldots 80^{\circ} \mathrm{T}$, а в контролі $84^{\circ}$ T. При досліджені зміни титрованої кислотності протягом зберігання встановлено, що у контрольному зразку за 14 діб титрована кислотність зросла до $132^{\circ} \mathrm{T}$, що $\epsilon$ максимальним для йогурту, а отже і смузі, а у зразку 3 до $116^{\circ} \mathrm{T}$. В абсолютних показниках найнижча величина титрованої кислотності за 14 діб зберігання була у зразку 3 при використанні більшої кількості насіння Чіа - 20 \%. На 21 добу зберігання у всіх зразках смузі титрована кислотність була вищою за допустиме значення.

\section{Висновки}

Розроблено рецептури та технологію виробництва смузі з фруктово-рослинним наповнювачем на основі йогурту, встановлено оптимальні кількості та способи внесення наповнювачів. Як наповнювачі використовували бананове та гарбузове пюре, а також насіння Чіа. За результатами органолептичної оцінки - для задоволення смакових потреб споживча і кращого зовнішнього вигляду, консистенції та кольору рекомендовано використовувати у технології смузі 50 \% молочної основи (йогурт), $20 \%$ бананового пюре, 20 \% гарбузового пюре та 10 \% насіння Чіа.

Внесення насіння Чіа вплинуло на енергетичну цінність продукту. Найвища енергетична цінність розрахована для зразка з використанням $20 \%$ насіння Чіа - 110 ккал. Найнижча енергетична цінність для контролю - 70,6 ккал, в якому переважає частка молочної основи. Внесення насіння Чіа у продукт зменшує кількість молочнокислих бактерій дослідних зразків смузі, що, зокрема, корелює із титрованою кислотністю продукту. При дослідженні наявності патогенної мікрофлори у зразках смузі встановлено, що всі зразки відповідали вимогам за мікробіологічною безпечністю. Кількість життєздатних клітин ацидофільної палички та біфідобактерій надає продукту пробіотичних властивостей. За результатами органолептичних показників - найкращий термін зберігання для смузі 14 діб. Всі зразки смузі після 14 доби мали кислий смак i запах та незначне виділення сироватки.
Найнижча величина титрованої кислотності за 14 діб зберігання була у зразку при використанні більшої кількості насіння Чіа - 20 \%. На 21 добу зберігання у всіх зразках смузі титрована кислотність була вищою за допустиме значення.

Для розширення асортименту молочних продуктів iз підвищеною харчовою цінністю та геродієтичними властивостями рекомендовано використовувати у технології смузі 50 \% молочної основи (йогурт), $20 \%$ бананового пюре, $20 \%$ гарбузового пюре та $10 \%$ насіння Чіа.

\section{References}

Alexeev, A., Alexeeva, T., Enaleva, L., Tupolskikh, T., \& Shumskaia, N. (2020). The use of biologically active components of plant and animal origin. XIII International Scientific and Practical Conference "State and Prospects for the Development of Agribusiness - INTERAGROMASH 2020”, 175. doi: 10.1051/e3sconf/202017508005.

Attalla, N. R., \& El-Neamah, E. A. (2017). Characteristics of Nutraceutical Yoghurt Mousse Fortified with Chia Seeds. International Journal of Environment, Agriculture and Biotechnology, 2(4), 2033-2046. doi: 10.22161/ijeab/2.4.61.

Castillejo, N., Martínez-Hernández, G. B., di Marco, G.; Azucena, P., Artés Calero, F., \& Artés Hernández, F. D. A. (2015). Red fresh vegetables smoothies with extended shelf life as an innovative source of healthpromoting compounds. J. Food Sci. Technol. Mysore, 53, 1475-1486. doi: 10.1007/s13197-015-2143-2.

Diakonova, A. K., \& Stepanova V. S. (2016). Porivnialnyi analiz biolohichnoi tsinnosti ta zdatnosti nasinnia chia i lonu do volohoutrymannia. Kharchova promyslovist, 19, 40-45 (in Ukrainian).

Dmytrovska, H. P. (2016). Kompleksnyi pidkhid do osuchasnennia asortymentu heromolochnoi produktsii. Problemы starenyia y dolholetyia, 25, 263-268 (in Ukrainian).

Dyakonova A., \& Stepanova V. (2016). Usage of the nut raw materials and chia seeds to improve fatty acid composition of the smoothies. Ukrainian Food Journal, 5(4), 713-723. doi: 10.24263/2304-974X2016-5-4-10.

Fontes, S. M., Cavalcanti, M. T., Candeia, R. A., \& Almeida, E. L. (2017). Characterization and study of functional properties of banana starch green variety of Mysore (Musa AAB - Mysore). Food Science and Technology, 37(2), 224-231. doi: 10.1590/1678457x.18916.

García-Burgos, M., Moreno-Fernández, J., Alférez, M. J. M., Díaz-Castro, J., \& López-Aliaga, I. (2020). New perspectives in fermented dairy products and their health relevance. Journal of Functional Foods, 72. doi: 10.1016/j.jff.2020.104059.

Gasmalla, M. A. A., Tessema, H. A., Salaheldin, A., Alahmad, K., Hassanin, H. A. M., \& Aboshora, W. (2017). Health benefits of milk and functional dairy products. MOJ Food Process Technol., 4(4), 108-111. doi: 10.15406/mojfpt.2017.04.00099. 
Gavrilova, N., Chernopolskaya, N., Rebezov, M., Moisejkina, D., Dolmatova, I., Mironova, I., Peshcherov, G., Gorelik, O., \& Derkho, M. (2019). Advanced Biotechnology of Specialized Fermented Milk Products. International Journal of Recent Technology and Engineering, 8, 2718-2722. doi: 10.35940/ijrte.B3158.078219.

González-Tejedor, G. A., Martínez-Hernández, G. B., Garre, A., Egea, J. A., Fernández, P.S., \& ArtésHernández, F. (2017). Quality changes and shelf-life prediction of a fresh fruit and vegetable purple smoothie. Food Bioprocess Technol, 10, 1892-1904. doi: 10.1007/s11947-017-1965-5.

Guazi, J. S., Lago-Vanzela, E. S., \& Conti-Silva, A. C. (2019). Development of smoothies from dehydrated products of strawberry and banana pulps obtained through foam-mat drying. Food Science and Technology, 54(1), 54-61. doi: 10.1111/ijfs.13900.

Kaur, S., Panghal, A., Garg, M. K., Mann, S., Khatkar, S. K., Sharma, P., \& Chhikara, N. (2019). Functional and nutraceutical properties of pumpkin - a review. Nutrition \& Food Science, 50(2), 384-401. doi: 10.1108/NFS-05-2019-0143.
Kulczynski, B., Kobus-Cisowska, J., Taczanowski, M., Kmiecik, D., \& Gramza-Michałowska, A. (2019). The Chemical Composition and Nutritional Value of Chia Seeds-Current State of Knowledge. Nutrients, 11, 1242. doi: 10.3390/nu11061242.

Ribeiro, I., Gomes, M., Figueiredo, D., Lourenço, J., Paúl, C., \& Costa, E. (2019). Dairy Product Intake in Older Adults across Europe Based On the SHARE Database. Journal of Nutrition in Gerontology and Geriatrics, 38, 297-306. doi: 10.1080/21551197.2019.1627972.

Sylchuk, T. A., Dochynets, I. V., \& Yurchenko, O. V. (2018). Rozroblennia smuzi herodiietychnoho pryznachennia. Mizhnarodnyi naukovyi zhurnal "Internauka", 10(2), 51-55 (in Ukrainian).

Tiwari, U. (2018). Production of fruit-based smoothies. Fruit Juices: Extraction, Composition, Quality and Analysis, 261-278. doi: 10.1016/B978-0-12-8022306.00014-X.

Tjurikova, I. S., \& Peresichnyj, M. I. (2015). Rozroblennja tehnologii' plodoovochevyh smuzi $\mathrm{z}$ vykorystannjam biologichno cinnogo volos'kogo goriha. Naukovyj visnyk Poltavs'kogo universytetu ekonomiky i torgivli. Serija: Tehnichni nauky, 1, 2737 (in Ukrainian) 